\title{
Levels of Heavy Metals in Human Hair and Nail Samples from Maiduguri Metropolis, Borno State, Nigeria
}

\author{
F. I. Abdulrahman, J.C. Akan", Z. M. Chellube, M. Waziri \\ Department of Chemistry, University of Maiduguri, P.M.B 1069, Maiduguri, Borno State, Nigeria \\ joechemakan@yahoo.com
}

\begin{abstract}
Hair and nail samples were collected from different subjects with respect to sex, age of those working in iron welder workshop and liquor and non-liquor subject in Maiduguri Metropolis, Borno State, Nigeria for heavy metals determination. Sample collection and preparations were carried out using standard procedures. The levels of heavy metals (Copper (Cu), Zinc (Zn), Copper (Co), Manganese (Mn), Iron (Fe), Chromium (Cr), Cadmium (Cd) Arsenic (As), Nickel (Ni) and Lead $(\mathrm{Pb})$ ) were carried out using Atomic Absorption Spectrophotometer (AAS, Unicam 969). From the results of this study, $\mathrm{Zn}$ showed the highest concentrations while $\mathrm{Cu}$ showed the least levels. The results of the study showed that there was no contribution of liquor towards nail and hair metal concentrations. The levels of all the metals studied were significantly higher in the toenails compared to fingernails samples $(\mathrm{p}<0.05)$. Similarly, iron welding workers showed high concentrations of heavy metals when compared to liquor user. The levels of all the metals studied were statistically higher in male subjects compared to female subjects $(p<0.05)$. The concentrations of heavy metals in nail samples were significantly higher when compared to hair samples. Significant levels of these metals in nail and hair samples indicate the presence of these metals in the environment and the workplace of the subjects. Since the present study reveals high levels of some heavy metals in hair and nail samples of iron welding worker volunteer. So there is instantaneous need for public awareness about the hazards of this occupation in order to enable these volunteer take necessary precautionary measures.
\end{abstract}

Keywords Heavy Metals, Work Place, Liquor, Hair, Nail

\section{Introduction}

The determination of trace element in hair has been the subject of continues interest in the biomedical and environmental sciences ${ }^{[1]}$. Hair can be considered to be an excretory product, the trace element contents of which reflect mineral metabolism in the body. However, their concentrations bear little relation to the levels in other tissues ${ }^{[2]}$. It should be noted that human hair is an attractive biological material because of the simplicity of sampling, transport and handling as well as providing information about concentrations of some trace elements that are considerably more concentrated in hair than in other biological materials, which makes analysis easier ${ }^{[3]}$. Trace elements accumulate in the body over given periods of time; therefore, they reflect the biomedical and environmental history of the body as well as long term metabolic changes ${ }^{[4,}$ ${ }^{5]}$. The importance of these examinations is attested by the fact that there are several trace elements in the human body that are important in biochemically processes. Some

* Corresponding author:

joechemakan@yahoo.com (J.C.Akan)

Published online at http://journal.sapub.org/env

Copyright (C) 2012 Scientific \& Academic Publishing. All Rights Reserved researchers have been carried out with the aim of correlating various diseases ${ }^{[3,6]}$. An excess or absence of these essential trace elements causes serious problems in the physiology of the body ${ }^{[7,8]}$. For example, a low level of essential elements such as $\mathrm{Ca}, \mathrm{Fe}, \mathrm{Zn}$ in human hair was found to be typical of deficiency diseases, metabolic disturbances and physiological disorders ${ }^{[9]}$. The trace elements incorporated into hair from within the body (endogenous) must be differentiated from contamination by external (exogenous) sources ${ }^{[9]}{ }^{[10]}$ have used hair analysis to check levels of arsenic and hazardous elements (e.g. $\mathrm{Zn}, \mathrm{Cu}, \mathrm{Cd}, \mathrm{Pb}$ ) as a way of monitoring environmental (chemical) sources of pollution. Various techniques have been employed in the detection of trace elements present in human hair. Among others, atomic fluorescence spectrometry ${ }^{[11]}$, atomic absorption spectrometry ${ }^{[12,13 ; 14,15]}$, inductively coupled plasma atomic emission spectrometry (ICP-AES) ${ }^{[5,6,13,16,17]}$, spectrofluorimetric ${ }^{[18]}$ and differential pulse anodic stripping voltammetry (DPASV) ${ }^{[19]}$ are widely used for trace element analysis. For example, the comparison between particle induced X-ray emission (PIXE) and neutron activation analysis (NAA) in determination of trace elements $(\mathrm{Cr}, \mathrm{Co}$, $\mathrm{Ni}, \mathrm{Se}, \mathrm{Hg}, \mathrm{Pb}, \mathrm{Cu}$ and $\mathrm{Zn}$ ) in human hair made by ${ }^{[20]}$.

Nail tissue is rich in fibrous proteins that contain keratins as cysteine residues ${ }^{[10]}$. Their roots are highly influenced by 
health status of the cells ${ }^{[10]}$, whereas blood and other body fluids give transient concentrations, human nails provide a continuous record of elemental concentration ${ }^{[10]}$. Nail growth in human is a continuous process throughout life, about $0.05-1.2 \mathrm{~mm}$ per week, with the toenails growing at a slower rate of 30-50 \% and thus provide a longer integration period for the metals ${ }^{[10]}$. Further, blood and other body fluids are not suitable to analyse levels of $\mathrm{Cd}$ because the metal exists briefly in the medium. Moreover, nails are easier to sample, transport and store since they do not require any external conditions unlike body fluids that are prone to contaminations. Analysis is economical which makes it a more attractive screening and diagnostic tool in developing countries. According to various studies, anyone could be poisoned by toxic metals but the most risk group are children under the age of six due to their not fully developed central nervous system and other organs, having more hand to mouth activities, untimely outdoor activities, not fully developed hygienic habits and active metabolism ${ }^{[10]}$. Studies have found that nutritional deficiencies of $\mathrm{Fe}, \mathrm{Ca}$ and $\mathrm{Zn}$, which are very prevalent in children in developing countries, may facilitate $\mathrm{Pb}$ and $\mathrm{Cd}$ absorption and their toxic effects [10]

Maiduguri (Lat. $11^{\circ} 50^{\prime} \mathrm{N}, \log .13^{\circ} 13^{\prime} \mathrm{E}$ ) is located in Borno state, occupies North east position of Northern Nigeria. It is underline by the sediments of the Chad basin. The temperature ranges from $22-28^{\circ} \mathrm{C}$, with means of the daily maximum exceeding the onset of the rain during March, April and May. It has a minimum temperature drop as low as $12^{\circ} \mathrm{C}$ in December-February. Studies have shown that there is a high accumulation of heavy metals in some human system in Borno State, which may be associated with exposure and inhalation of these metals from the environment. This trend poses a major health challenge to human system. But there are no detailed documented baseline data of the levels of heavy metals in Hair and nail samples in this area of study, hence the need for this study. This study is aim at determining heavy metals, which include copper, zinc, iron, lead, chromium, cobalt, manganese, cadmium, arsenic, and nickel in human hair, fingernail and toenail samples of different sex, age groups of (iron welding workers and liquor users and non-liquor users.

\subsection{Materials and Methods}

\subsubsection{Sampling Area and Sample Collection}

Hair and nail samples were from different subjects within Maiduguri Metropolis Borno State, Nigeria. Samples were collected from subjects with respect to sex, age and those working in iron welding workshop and liquor users and non-liquor users. Hair samples of male subjects of age range (0-10, 11-20, 21-30, 31-40, 41-50, 51-60 and 60-above years) were collected from the nape of the scalp by cutting $2 \mathrm{~mm}$ from the scalp using a pair of sterilized stainless steel scissors washed with ethanol, a neutral solvent to remove external contamination. The hair samples collected were sealed in plastic bags prior to analysis.
For collection of nail samples the male and female volunteers were ask to wash their hand and toes thoroughly with medicated soap and rinse with double deionized water to avoid metal contamination, followed by drying with a clean towel or tissue to remove external contamination. Fingernail and toenail samples of male and female subjects of age range (11-20, 21-30, 31-40, 41-50, 51-60 and 60 -above years) were cut with sterilized stainless steel scissors. All the nails samples were also sealed in plastic bags prior to analysis.

\subsubsection{Procurement of Requisite Details of Subject}

The personal and medical histories, along with relevant details of the subjects taken for study were obtained through a questionnaire based on recommendation of World Health Organisation (WHO). The detail information's include sex, age, occupation and habit.

\subsubsection{Washing of Hair Samples}

The hair samples were cut into pieces so as to ensure feasible and fast digestion of the samples. Hair samples were pre-washed with nonionic detergent and soaked in deionized water for 10 minute. It was followed by soaking in acetone to remove external contamination and finally the hair samples were washed with deionized water. The samples were dried in an oven at $110{ }^{\circ} \mathrm{C}$ for 1 hour and finally kept in a desiccators pending analysis.

\subsubsection{Washing of Nail Samples}

The nail samples were scrape and clean of dust particles with nonionic detergent (Triton X-100) following a standardized washing procedure ${ }^{[21]}$. This was followed by soaking the nail samples in acetone to remove external contamination, and finally the samples were rinse five times with deionized water, dried in an oven at $110{ }^{\circ} \mathrm{C}$ and stored in a dessicator pending analysis.

\subsubsection{Digestion of Hair Samples}

For each of the hair samples, $3 \mathrm{~g}$ was weighed into a clean crucible. It was dried in the oven to partial dryness to avoid explosion. The dried hair samples were digested with $10 \mathrm{ml}$ of 6:1 mixture of concentrated nitric acid and perchloric acid, the mixture were heated until complete evaporation to obtain a water clear solution. Each digested samples were transferred into a $100 \mathrm{~mL}$ volumetric flask and made up to the mark with distilled water.

\subsection{Digestion of Nail Samples}

The dried nail samples $(1 \mathrm{~g})$ were place in a furnace and ashes at $550{ }^{\circ} \mathrm{C}$ for 4 hours. The ashes were digested with 10 $\mathrm{ml}$ of $6: 1$ mixture of concentrated nitric and perchloric acid kept overnight at room temperature to prevent excessive foaming and subsequently the samples were heated at $160-180{ }^{\circ} \mathrm{C}$ until the mixture become water clear and reduces to $1 \mathrm{ml}$. Each sample solution was then diluted with $0.1 \mathrm{~N}$ nitric acid and made to a volume of $50 \mathrm{ml}$ with distilled 
water.

\subsubsection{Elemental Analysis of Samples}

Determination of $\mathrm{Cu}, \mathrm{Zn}, \mathrm{Co}, \mathrm{Mn}, \mathrm{Fe}, \mathrm{Cr}, \mathrm{Cd} \mathrm{As}, \mathrm{Ni}$ and $\mathrm{Pb}$ were made directly on each final solution using Atomic Absorption Spectrophotometer (AAS, Unicam 969). Standard solution of each sample $\mathrm{Cu}, \mathrm{Zn}, \mathrm{Co}, \mathrm{Mn}, \mathrm{Fe}, \mathrm{Cr}, \mathrm{Cd}$ $\mathrm{As}, \mathrm{Ni}$ and $\mathrm{Pb}$ were prepared according to $\mathrm{Sc} 2000$ manufacturer procedure for Atomic absorption spectroscopy to be used. A known $1000 \mathrm{mg} / \mathrm{l}$ concentration of the metal solution was prepared from their salts.

\section{Results}

The concentration of heavy metals from male subject working in iron welding workshop is as presented in Figure 1. The mean concentrations of $\mathrm{Zn}$ ranged from 17.98 to 70.00 $\mu \mathrm{g} / \mathrm{g} ; 19.45$ to $55.67 \mu \mathrm{g} / \mathrm{g} \mathrm{Pb} ; 27.43$ to $45.00 \mu \mathrm{g} / \mathrm{g} ; \mathrm{Fe} ; 7.80$ to $16.37 \mu \mathrm{g} / \mathrm{g} \mathrm{Ni} ; 1.44$ to $4.71 \mu \mathrm{g} / \mathrm{g} \mathrm{As} ; 1.34$ to $4.54 \mu \mathrm{g} / \mathrm{g} \mathrm{Cd}$; 6.94 to $17.34 \mu \mathrm{g} / \mathrm{g} \mathrm{Cr} ; 9.66$ to $15.44 \mu \mathrm{g} / \mathrm{g} \mathrm{Mn} ; 1.66$ to 4.00 $\mu \mathrm{g} / \mathrm{g} \mathrm{Cu}$. From Figure 1, the levels of all the metals increase with respect to age. The levels of the metals were in the following order $\mathrm{Zn}>\mathrm{Pb}>\mathrm{Fe}>\mathrm{Ni}>\mathrm{Cr}>\mathrm{Mn}>\mathrm{As}>\mathrm{Cd}>\mathrm{Cu}$.

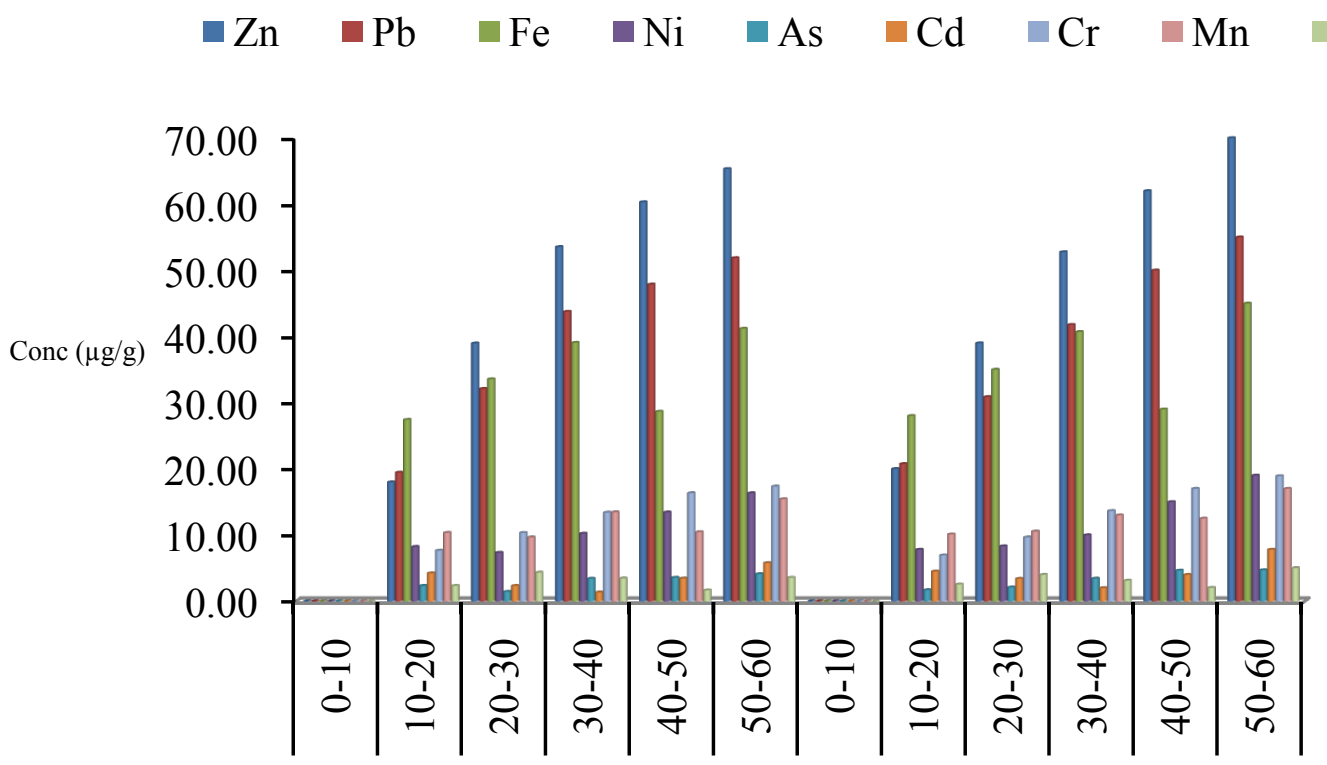

Figure 1. Mean concentrations of heavy metals in fingernail and toenail samples from Male subject working in iron Welder workshop with respect to age group in Maiduguri Metropolis

$$
\square \mathrm{Zn} \quad \mathrm{Pb} \quad \square \mathrm{Fe} \quad \square \mathrm{Ni} \quad \mathrm{As} \quad \square \mathrm{Cd} \quad \square \mathrm{Cr} \quad \square \mathrm{Mn} \quad \square \mathrm{Cu}
$$

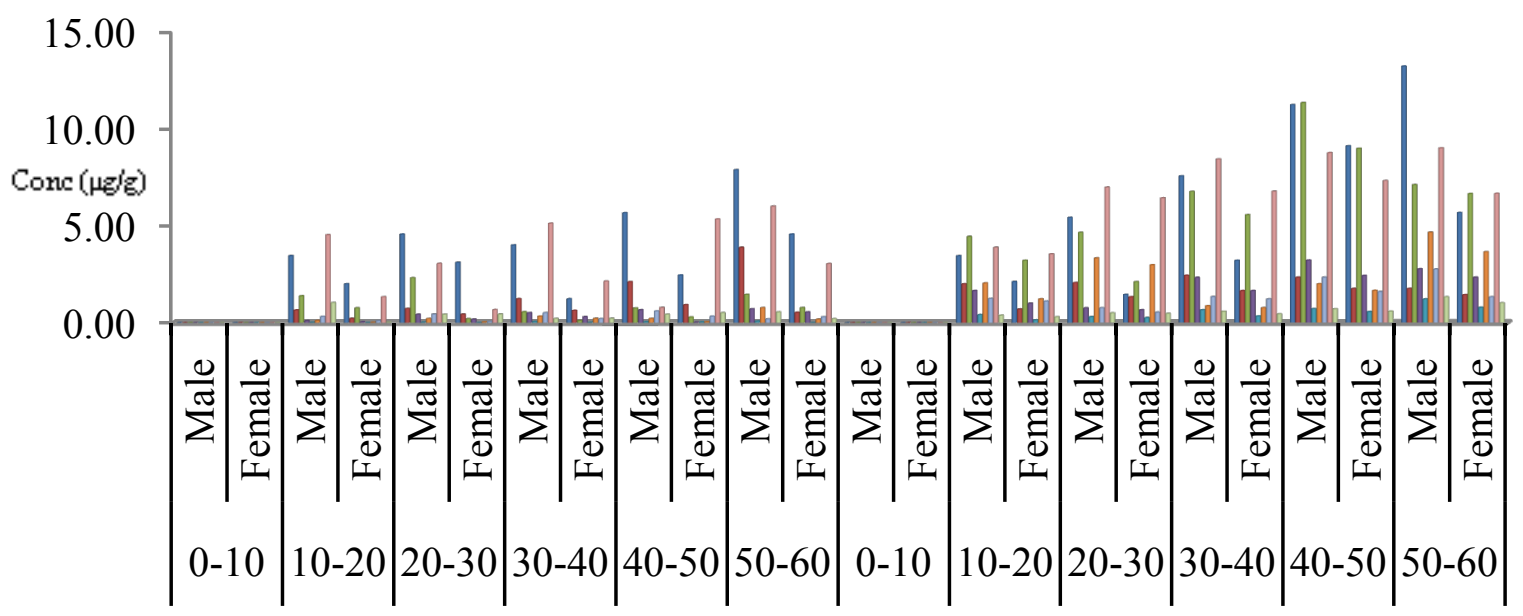

Figure 2. Mean concentrations of heavy metals in fingernail samples from Male and female liqour users and non-liqour users with respect to age group in Maiduguri Metropolis 


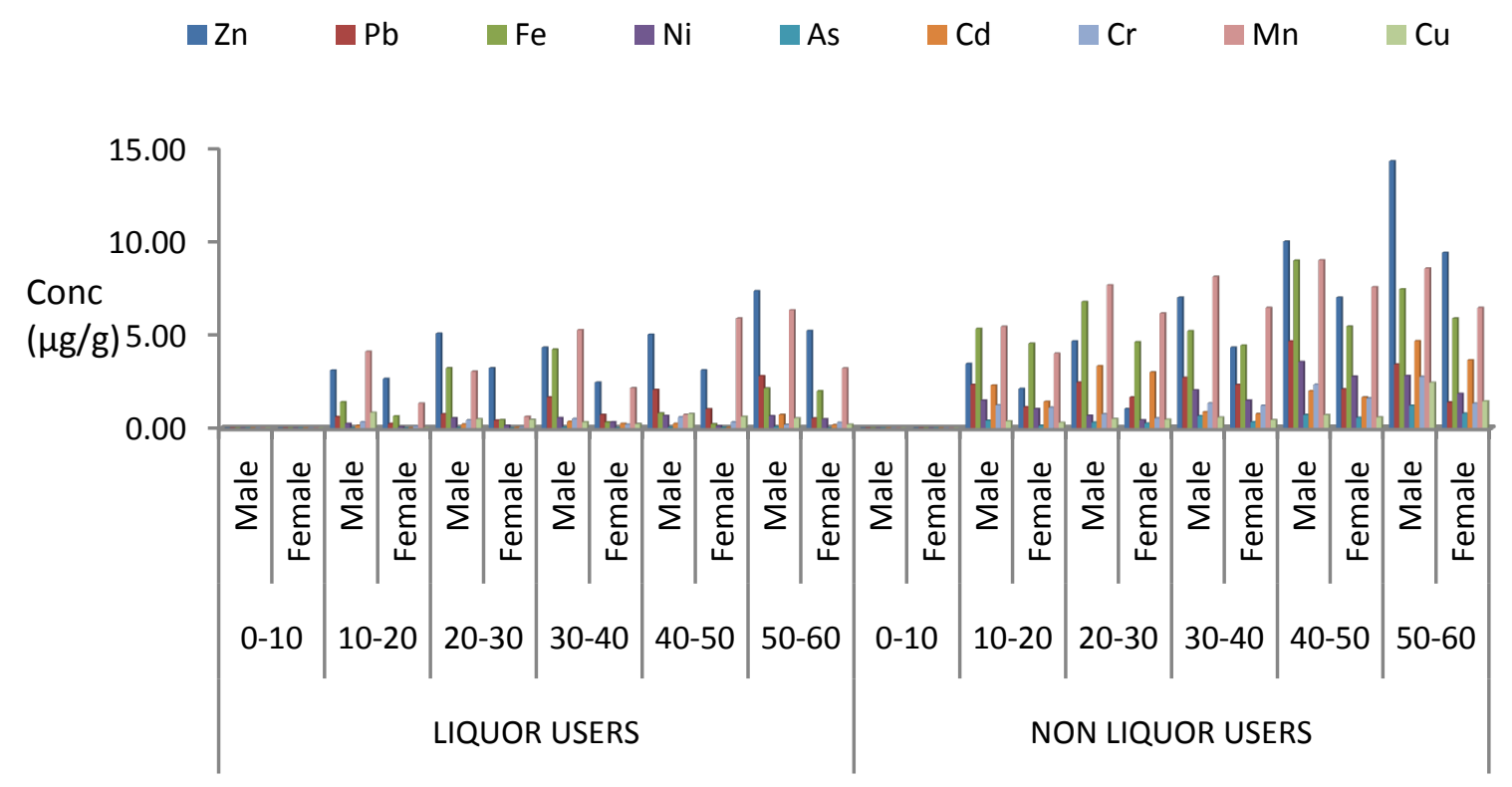

Figure 3. Mean concentrations of heavy metals in toenail samples from Male and female liqour users and non-liqour users with respect to age group in Maiduguri Metropolis

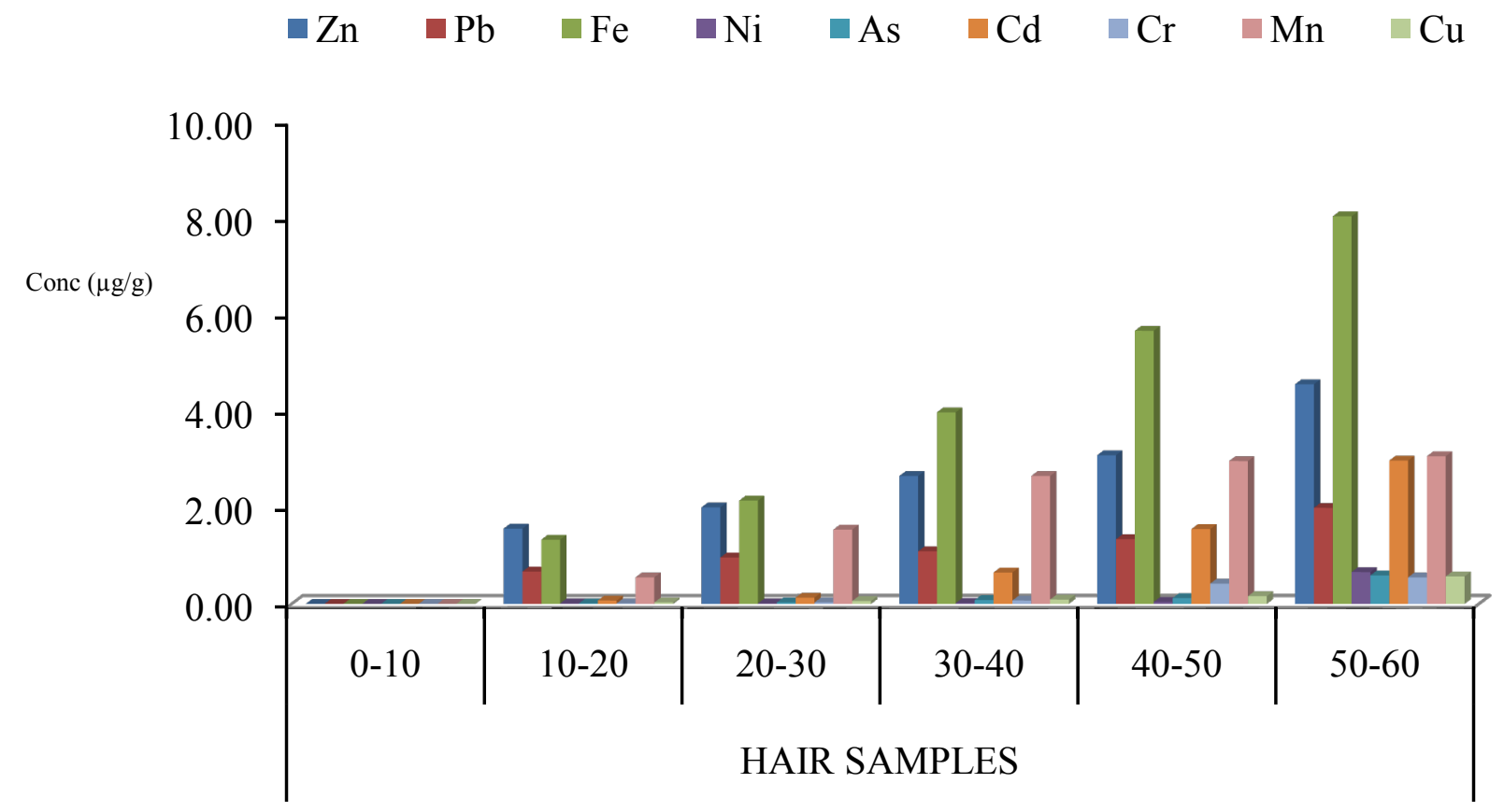

Figure 4. Mean concentrations of heavy metals in hair samples from Male sublect working in iron welding workshop with respect to age groups in Maiduguri Metropolis 


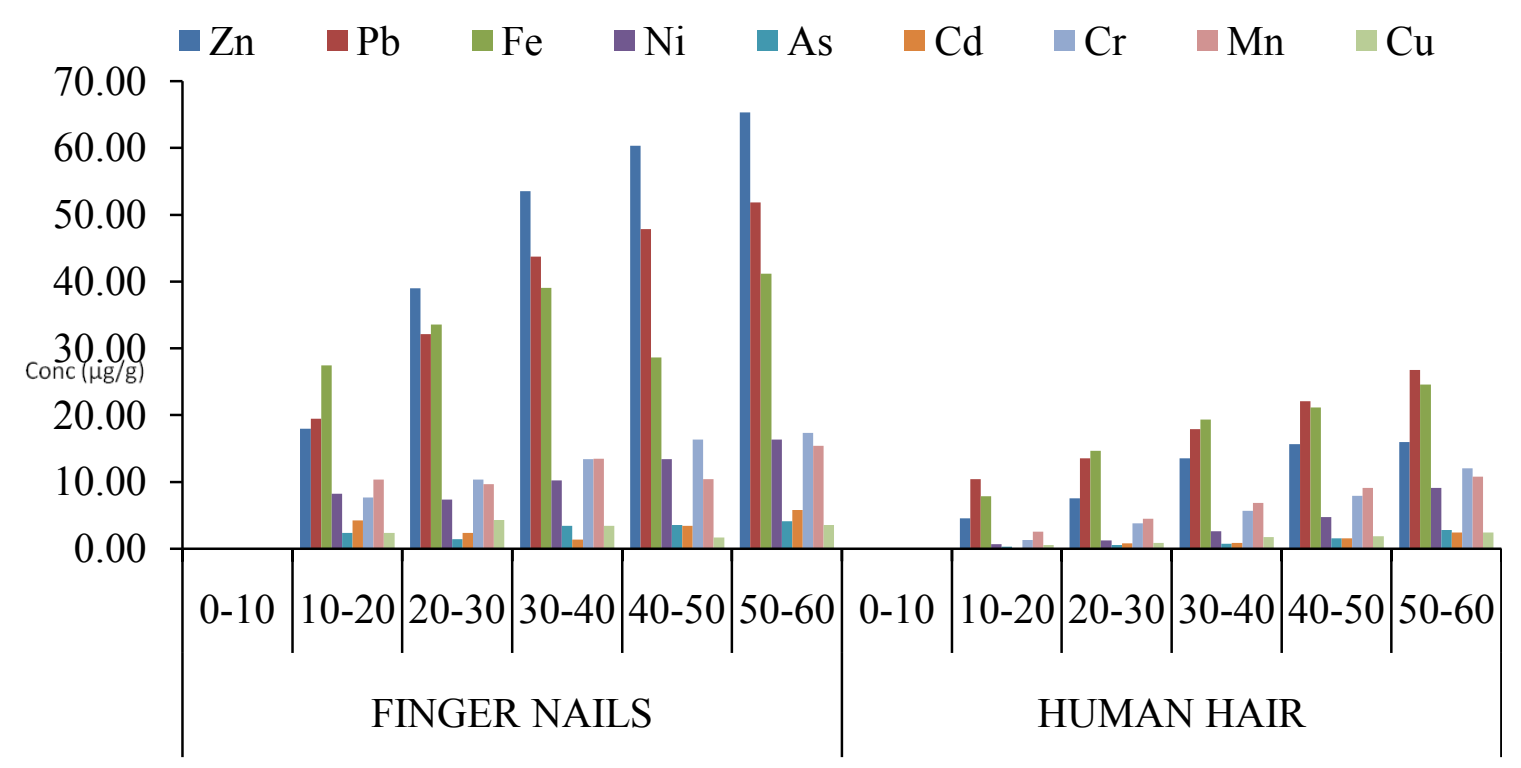

Figure 5. Comparison in the concentrations of heavy metals between fingernail and human hair samples from same Male iron welding workers with respect to age groups in Maiduguri Metropolis

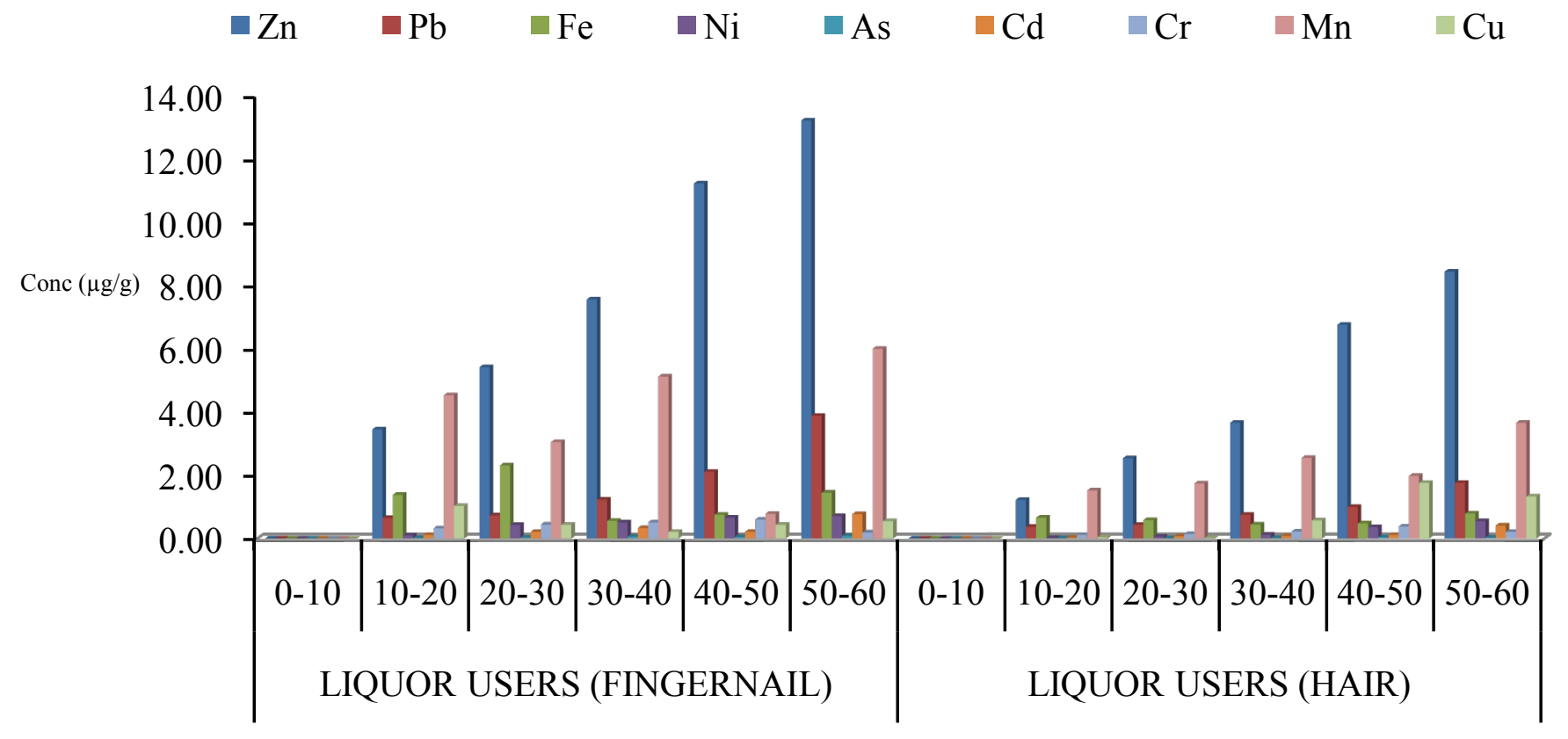

Figure 6. Comparison in the concentrations of heavy metals between fingernail and hair samples from same Male liquor users with respect to age groups in Maiduguri Metropolis 
Table 1. Mean concentrations of heavy metals in hair samples from Male liquor users and non-liquor users with respect to age groups in Maiduguri Metropolis

\begin{tabular}{|c|c|c|c|c|c|c|c|c|c|c|}
\hline & Age Group & $\mathrm{Zn}$ & $\mathrm{Pb}$ & $\mathrm{Fe}$ & $\mathrm{Ni}$ & As & $\mathrm{Cd}$ & $\mathrm{Cr}$ & $\mathrm{Mn}$ & $\mathrm{Cu}$ \\
\hline \multirow{6}{*}{ 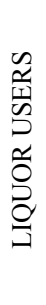 } & $0-10$ & 0.00 & 0.00 & 0.00 & 0.00 & 0.00 & 0.00 & 0.00 & 0.00 & 0.00 \\
\hline & $10-20$ & 0.34 & 0.33 & 0.03 & 0.14 & 0.10 & 0.01 & 0.59 & 0.65 & 0.01 \\
\hline & $20-30$ & 0.55 & 0.71 & 0.45 & 0.33 & 0.17 & 0.02 & 0.22 & 0.88 & 0.01 \\
\hline & $30-40$ & 1.05 & 1.06 & 0.76 & 0.87 & 0.31 & 0.02 & 0.74 & 1.00 & 0.16 \\
\hline & $40-50$ & 2.44 & 0.73 & 0.84 & 1.04 & 0.42 & 0.11 & 1.04 & 1.22 & 0.44 \\
\hline & $50-60$ & 2.98 & 1.00 & 1.07 & 1.80 & 0.79 & 0.22 & 1.77 & 1.67 & 0.76 \\
\hline \multirow{6}{*}{ 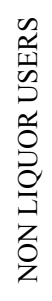 } & $0-10$ & 0.00 & 0.00 & 0.00 & 0.00 & 0.00 & 0.00 & 0.00 & 0.00 & 0.00 \\
\hline & $10-20$ & 1.22 & 0.37 & 0.66 & 0.02 & 0.01 & 0.03 & 0.11 & 1.52 & 0.04 \\
\hline & $20-30$ & 2.54 & 0.43 & 0.58 & 0.06 & 0.01 & 0.07 & 0.14 & 1.74 & 0.02 \\
\hline & $30-40$ & 3.66 & 0.75 & 0.44 & 0.12 & 0.02 & 0.08 & 0.22 & 2.55 & 0.57 \\
\hline & $40-50$ & 6.76 & 1.00 & 0.48 & 0.36 & 0.04 & 0.11 & 0.38 & 1.98 & 1.76 \\
\hline & $50-60$ & 8.44 & 1.76 & 0.79 & 0.55 & 0.03 & 0.41 & 0.21 & 3.66 & 1.33 \\
\hline
\end{tabular}

The concentrations of heavy metals in fingernail samples from liquor users and non-liquor users in male and female subject in different age group is as presented in Figure 2. $\mathrm{Zn}$ concentrations ranged from 1.23 to $13.22 \mu \mathrm{g} / \mathrm{g} ; 1.33$ to 3.88 $\mu \mathrm{g} / \mathrm{g} \mathrm{Pb} ; 2.11$ to $11.34 \mu \mathrm{g} / \mathrm{g} ; \mathrm{Fe} ; 0.05$ to $3.22 \mu \mathrm{g} / \mathrm{g} \mathrm{Ni} ; 0.01$ to $1.22 \mu \mathrm{g} / \mathrm{g}$ As; 0.04 to $4.66 \mu \mathrm{g} / \mathrm{g} \mathrm{Cd} ; 0.54$ to $2.76 \mu \mathrm{g} / \mathrm{g} \mathrm{Cr}$; 0.67 to $9.00 \mu \mathrm{g} / \mathrm{g} \mathrm{Mn} ; 0.03$ to $1.33 \mu \mathrm{g} / \mathrm{g} \mathrm{Cu}$. The levels of heavy metals in toenail samples from liquor users and non liquor users are as presented in Figure 3. levels of $\mathrm{Zn}$ ranged from 1.04 to $14.30 \mu \mathrm{g} / \mathrm{g} ; 0.24$ to $4.66 \mu \mathrm{g} / \mathrm{g} \mathrm{Pb} ; 0.22$ to 7.45 $\mu \mathrm{g} / \mathrm{g} ; \mathrm{Fe} ; 0.07$ to $3.56 \mu \mathrm{g} / \mathrm{g} \mathrm{Ni} ; 0.01$ to $1.22 \mu \mathrm{g} / \mathrm{g} \mathrm{As} ; 0.02$ to $4.67 \mu \mathrm{g} / \mathrm{g} \mathrm{Cd} ; 0.10$ to $2.80 \mu \mathrm{g} / \mathrm{g} \mathrm{Cr} ; 0.62$ to $8.56 \mu \mathrm{g} / \mathrm{g} \mathrm{Mn}$; 0.02 to $2.44 \mu \mathrm{g} / \mathrm{g} \mathrm{Cu}$. Male subject shows the highest concentrations compared to the females subject and also these increase with respect to age. Metal concentrations Figure 2 and 3) were higher in non-liqor users when compared to liquor users. Statistic shows that they were significant difference between the concentrations of heavy metals in the fingernail samples when compared to toenail samples.

Figure 4 shows the concentrations of heavy metals in human hair from male subject working in iron welding workshop. The mean concentrations of $\mathrm{Zn}$ ranged from 1.56 to $4.55 \mu \mathrm{g} / \mathrm{g} ; 0.67$ to $1.99 \mu \mathrm{g} / \mathrm{g} \mathrm{Pb} ; 1.33$ to $8.03 \mu \mathrm{g} / \mathrm{g} ; \mathrm{Fe} ; 0.01$ to $0.66 \mu \mathrm{g} / \mathrm{g} \mathrm{Ni} ; 0.01$ to $0.59 \mu \mathrm{g} / \mathrm{g}$ As; 0.07 to $2.97 \mu \mathrm{g} / \mathrm{g} \mathrm{Cd}$; 0.01 to $0.55 \mu \mathrm{g} / \mathrm{g} \mathrm{Cr} ; 0.55$ to $3.06 \mu \mathrm{g} / \mathrm{g} \mathrm{Mn} ; 0.03$ to $0.57 \mu \mathrm{g} / \mathrm{g}$ $\mathrm{Cu}$.

The concentrations of heavy metals in male hair samples from liquor users and non-liquor users of different age group are as presented in Table $1 . \mathrm{Zn}$ concentrations ranged from 1.22 to $8.44 \mu \mathrm{g} / \mathrm{g} ; 1.33$ to $3.88 \mu \mathrm{g} / \mathrm{g} \mathrm{Pb} ; 0.03$ to $1.07 \mu \mathrm{g} / \mathrm{g}$; Fe; 0.02 to $1.80 \mu \mathrm{g} / \mathrm{g} \mathrm{Ni} ; 0.01$ to $0.79 \mu \mathrm{g} / \mathrm{g} \mathrm{As} ; 0.01$ to $0.41 \mu \mathrm{g} / \mathrm{g}$ $\mathrm{Cd} ; 0.11$ to $1.77 \mu \mathrm{g} / \mathrm{g} \mathrm{Cr} ; 0.65$ to $1.67 \mu \mathrm{g} / \mathrm{g} \mathrm{Mn} ; 0.01$ to 1.76 $\mu \mathrm{g} / \mathrm{g} \mathrm{Cu}$. The levels of these metals increase with respect to age. Statistically there were no significant differences between the concentrations of heavy metals in liquor users subject when compared with non-liquor users $(\mathrm{p}<0.05)$.
Figure 5 shows a comparison in the concentrations of heavy metals between fingernails and hair with respect to age from same male subject working in iron welding workshop. The levels of $\mathrm{Zn}$ in fingernail samples is 14.60 to $70.00 \mu \mathrm{g} / \mathrm{g} ; 0.78$ to $30.44 \mu \mathrm{g} / \mathrm{g} \mathrm{Pb} ; 4.87$ to $48.55 \mu \mathrm{g} / \mathrm{g}$; Fe; 1.23 to $11.34 \mu \mathrm{g} / \mathrm{g} \mathrm{Ni} ; 0.03$ to $9.43 \mu \mathrm{g} / \mathrm{g}$ As; 0.23 to $3.23 \mu \mathrm{g} / \mathrm{g}$ $\mathrm{Cd} ; 0.34$ to $11.87 \mu \mathrm{g} / \mathrm{g} \mathrm{Cr} ; 1.23$ to $16.21 \mu \mathrm{g} / \mathrm{g} \mathrm{Mn} ; 0.32$ to $5.77 \mu \mathrm{g} / \mathrm{g} \mathrm{Cu}$. For hair samples the levels of $\mathrm{Zn}$ ranged from 12.34 to $44.00 \mu \mathrm{g} / \mathrm{g} ; 6.70$ to $12.4 \mu \mathrm{g} / \mathrm{g} \mathrm{Pb} ; 24.45$ to 38.00 $\mu \mathrm{g} / \mathrm{g} ; \mathrm{Fe} ; 4.56$ to $11.45 \mu \mathrm{g} / \mathrm{g} \mathrm{Ni} ; 1.08$ to $3.87 \mu \mathrm{g} / \mathrm{g}$ As; 0.67 to $2.06 \mu \mathrm{g} / \mathrm{g} \mathrm{Cd} ; 0.2 .67$ to $4.06 \mu \mathrm{g} / \mathrm{g} \mathrm{Cr} ; 2.56$ to $6.76 \mu \mathrm{g} / \mathrm{g} \mathrm{Mn}$; 0.06 to $1.67 \mu \mathrm{g} / \mathrm{g} \mathrm{Cu}$. This results shows that the concentrations of all the metals in the hair and fingernail samples in the male subject increase with increased in age. Also fingernail samples accumulated higher concentrations of heavy metals when compared with hair samples.

The levels of heavy metals in fingernail samples compared to hair samples from liquor users of same subject is as presented in Figure 6. Zn concentrations ranged from 1.22 to $13.22 \mu \mathrm{g} / \mathrm{g} ; 0.37$ to $3.88 \mu \mathrm{g} / \mathrm{g} \mathrm{Pb} ; 0.44$ to $1.45 \mu \mathrm{g} / \mathrm{g} ; \mathrm{Fe} ; 0.02$ to $0.71 \mu \mathrm{g} / \mathrm{g} \mathrm{Ni} ; 0.01$ to $0.08 \mu \mathrm{g} / \mathrm{g}$ As; 0.03 to $0.77 \mu \mathrm{g} / \mathrm{g} \mathrm{Cd}$; 0.11 to $0.60 \mu \mathrm{g} / \mathrm{g} \mathrm{Cr} ; 0.78$ to $3.66 \mu \mathrm{g} / \mathrm{g} \mathrm{Mn} ; 0.04$ to $1.76 \mu \mathrm{g} / \mathrm{g}$ $\mathrm{Cu}$.

\section{Discussion}

The results of this study shows that heavy metals in nails and hair samples from different subject accumulate differently based on exposure. It was observed that the highest concentration of $\mathrm{Zn}(70.00 \mu \mathrm{g} / \mathrm{g})$ was obtained in toenail of subject from iron welder workers. The levels of $\mathrm{Pb}$ 55.33 was highest in the toenail of subject from iron welding worker when compared to liquor users and non liquor users, such differences recorded might be attributed to exposure of subject working in iron welder workshop ${ }^{[22,23]}$. This indicates that the concentrations of metals in the body is a 
function of metal in the work environment, this was in line with the work of ${ }^{[24]}$. Similar trend were observed for $\mathrm{Fe}, \mathrm{Ni}$, $\mathrm{As}, \mathrm{Cd}, \mathrm{Cr}, \mathrm{Mn}$ and $\mathrm{Cu}$ with elevated level in toenail than fingernail samples, the high levels of all the metals in toenail samples when compared to fingernail samples might be attributed to the fact that fingernail grows continuous at a faster rate of 0.05-1.2 mm per week while toenails grows at a slower rate and thus provide a longer integrated period for the metals accumulation compared to fingernail ${ }^{[25]}$.

Nail samples were observed to accumulate higher concen trations of heavy metals when compared to hair samples such differences might be attributed to the incorporation of elements into the keratin structure of hair which takes place by binding to the sulfhydryl groups that are present in the follicular protein. In this regard, the detergents such as soap, and shampoos, hair pomades, lotions, hair bleaches and dyes actually compete with the complexing ability of these reactive sites, thus leading to a significant leaching of elements from the shaft bulk ${ }^{[26]}$. Iron welders showed higher concentrations of heavy metals when compared to liquor users and non liquor users, such variation might be attributed to the fact that the major sources of heavy metals in occupational exposed worker includes batteries, alloys and electroplating metal parts among others ${ }^{[27]}$, while for nonoccupational exposed adults are from food and drink according to World Health organization ${ }^{[28]}$.

High level of iron observed in this study might be probably due to the presence of iron oxide fumes in the environment of workplace as various processes involved emanate oxides of iron. Besides this, the inhalation of vapors of nickel carbonyl from the worktype (iron welding worker) also causes elevation in Ni levels. No significant variation was observed in the levels of heavy metals between liquor users non-liquor users, which show that liquor is not a contributing factor to metal accumulation, since there is no source of metals during the production of liquor. The presence of all the metals in non-liquor user could be attributed to the environmental exposure. The concentrations of all the metal studied in hair and nail samples from iron welder worker and liquor users and non liquor users subject increases significantly from 10-20years to 50-60 years. The younger group showed least levels when compared with the older groups. Nail samples from same subject also showed significantly high levels of heavy metals when compared to hair samples.

\subsection{Chromium (Cr)}

Chromium (VI) compounds are toxics and known human carcinogens, whereas chromium (III) is an essential element. Breathing high levels can cause irritation to the lining of the nose; nose ulcers; running nose; and breathing problems, such as asthma, cough, shortness of breath, or wheezing. Long term exposure can cause damage to liver, kidney, circulatory and nerve disorders, as well as skin irritation ${ }^{[29]}$. Compare the Cr content of the samples with the levels in hair and nails for healthy individual from various countries $\mathrm{Cr}$ in
Italy ${ }^{[26]}$ is 0.03 to $19.7 \mathrm{mg} / \mathrm{kg}$, England ${ }^{[30]} 0.03$ to 1.88 $\mathrm{mg} / \mathrm{kg}$. Based on these values it is clear that the concentrati ons of heavy metals in hair and nails samples were higher than the lower limits for other countries. It implies that the $\mathrm{Cr}$ content of each of the samples is above the permissible limit, Hence, considering the bioaccumulation nature of $\mathrm{Cr}$ and the pattern of exposure as showed in the results one cannot rule out the long term health complications of $\mathrm{Cr}$ in the various subject.

\subsection{Iron (Fe) and Copper $(\mathrm{Cu})$}

Toxicity of iron in humans has been found to bring about vomiting, cardiovascular collapse and diarrhoea. While iron deficiency may lead to failure of blood clotting ${ }^{[31]}$. Copper is a common environmental metal and is essential in cellular metabolism but at high concentrations it can be highly toxic to fish ${ }^{[32]}$. Copper is an essential substance to human life, however, in high concentrations, it can cause anaemia, liver and kidney damage, stomach and intestinal irritation ${ }^{[31]}$. Copper is generally remobilised with acid-base ion exchange or oxidation mechanism ${ }^{[33]}$. Copper is an essential substance to human life, but its critical doses can cause anemia, adrenal hyperactivity and insufficiency, allergies, hair loss, arthritis, autism, cancer, depression, elevated cholesterol, depression, diabetes, dyslexia, failure to thrive, fatigue, fears, fractures of the bones, headaches, heart attacks, hyperactivity, hypertension, infections, panic attacks, strokes, tooth decay and vitamin $\mathrm{C}$ and other vitamin deficiencies ${ }^{[29]}$. Copper is a common environmental metal and is essential in cellular metabolism but at high concentrations it can be highly toxic to fish ${ }^{[32]}$. Copper is an essential substance to human life, however, in high concentrations, it can cause anaemia, liver and kidney damage, stomach and intestinal irritation. Copper is generally remobilised with acid-base ion exchange or oxidation mechanism ${ }^{[33]}$. Long term exposure of copper may lead to liver and kidney damage. Iron and Copper concentrations were generally lower in the entire sample analyzed when compared to other researchers [26, ${ }^{30]}$. Therefore, the levels of all the metals in the subject studied were within the stipulated limits. The toxicity of potentials of copper are quite low compared to other heavy metals, however, exposure to very high doses could cause severe health effect.

\subsection{Arsenic (As)}

Arsenic is regarded as human carcinogen from extremely low levels of exposure, having no possible beneficial meta-bolic functions for humans ${ }^{[27]}$. Its low level exposure cause nausea and vomiting decreased production of RBCs and WBCs, abdominal pain and its long term exposure causes darkening of skin and appearance of small corns on palm soles. Other affect includes abnormal ECG, anorexia, fever, fluid loss, goitre, hair loss, headache, herpes, im-paired healing, jaundice, keratosis, kidney and liver damage, muscle spasms, pallor, peripheral neuritis, sore throat, weakness and interferes with the uptake of folic acid 
[27]. Arsenic (As) levels in the hair samples were above the reference values of England ${ }^{[30]} 0.02 \mathrm{mg} / \mathrm{kg}$. Based on the results of this study, one cannot rule out the long term health complications of As in the various subject.

\subsection{Cadmium (Cd)}

Cadmium is very toxic, its long-term exposure to lower levels leads to a build up in the kidneys and possible kidney disease, lung damage, and fragile bones. Hypertension, ar-thritis, diabetes, anaemia, cancer, cardiovascular disease, cirrhosis, reduced fertility; hypoglycemia, headaches, kidney disease, and strokes are its some odd long term results ${ }^{[27]}$. The levels of cadmium in the hair samples were above the reference values of various countries Italy ${ }^{[26]}$ is $0.03 \mathrm{mg} / \mathrm{kg}$, England [30] $0.11 \mathrm{mg} / \mathrm{kg}$, Japan ${ }^{[34]} 0.05 \mathrm{mg} / \mathrm{kg}$. . The bioaccumulation nature of $\mathrm{Cd}$ and the pattern of exposure as showed in the results, one cannot rule out the long term health complications of $\mathrm{Cd}$ in the various subject.

\subsection{Nickel (Ni)}

Nickel is known to be responsible for cancer(oral and intestinal), depression, heart attacks, haemorrhages, kidney dysfunction, low blood pressure, malaise, muscle tremors and paralysis, nausea, skin problems and vomiting ${ }^{[27]}$. The levels of nickel were spatially and temporary high in the hair and nail samples. A comparism of $\mathrm{Ni}$ concentration in the hair samples with that of ${ }^{[26,30]}$ showed that the concentration of $\mathrm{Ni}$ in hair samples were high and indication of possible accumulation of $\mathrm{Ni}$. However, long term exposure can cause decreased body weight, heart and liver damage and skin irritation.

\subsection{Lead (Pb)}

Lead enters into the body system through air, water and food and cannot be removed by washing fruits and vegetables ${ }^{[35]}$. It is a serious cumulative body poison, which can affect every organ and system in the body. Exposure to its high levels can severely damage the brain, kidneys and ultimately cause death and long-term exposure result in de-creased performance in some tests that measure the functions of the nervous system; weakness in fingers, wrists, or ankles; small increases in blood pressure; and anaemia. Others are abdominal pain, anaemia, arthritis, attention deficit, back problems, blindness, cancer, constipation, con-vulsions, depression, diabetes, migraine headaches, thyroid imbalances and tooth decay. Children exposed to high lead levels are particularly at risk. The levels of lead in the analyzed hair samples for the entire subject studied exceeded the upper limits for the various countries Italy ${ }^{[26]}$ is $0.03 \mathrm{mg} / \mathrm{kg}$; Japan ${ }^{[34]} 1.4 \mathrm{mg} / \mathrm{kg}$ ). Indicating the presence of this metal in the environment and the workplace of the subjects as well as their proneness to illness and hazards of this metal in cases of long term exposure.

\section{Conclusions}

Since the present study reveals high levels of some heavy metals in hair and nail samples of iron welding worker volunteer. So there is instantaneous need for public awareness about the hazards of this occupation in order to enable these volunteer take necessary precautionary measures. It is also deemed essential that certain preventive measures including use of hand gloves and masks should be taken to safe guard the health of the subject working in iron welding workshop.

\section{REFERENCES}

[1] Arnold, W and Sachs, H. (1994). Hair analysis for medicaments - the best proof for a drug career, Freseniu. Journal of Analytical Chemistry.348:484-489.

[2] Kaluza. J., Jeruszka, M and Brzozowska, A. (2001). Iron, zinc and copper status of elderly people living in Warsaw district determined by hair analysis, Roczniki Pañstwowego Zak ${ }^{3}$ adu Higieny. 52: 111-118.

[3] Zhunk L. I and Kist, A. A (1995). Human hair instrumental neutron activation analysis and medicine, Journal of Radioanalytical and Nuclear Chemistry, vol. 195, pp. 75-81

[4] Suhonen R. P. R and Dawber D. H (1999). Fungal infection of the skin, hair and nails, Martin Dunitz, London.

[5] D ' I 1 i o, S., Violante, N and Senefonte, O. (2000). Occupational exposure of goldsmith workers of the area of Rome to potentially toxic metals as monitored through hair analysis, Microchemical Journal. 67:343-349

[6] Wang, C. Y., Zhou Y. M., Yang W. Z., Multielement (1995). ICP-AES analysis of hair samples and a chemometrics study for cancer diagnosis, Microchemical Journal, 1995, vol. 51, pp. 5-14.

[7] Dombovári, J and Papp, L. (1998). Comparison of sample preparation methods for elemental analysis of human hair, Microchemical Journal. 59:187-193.

[8] Dombovári, J., Papp, L and Uzonyi, I. (1999). Study of cross-sectional and longitudinal distribution of some major and minor elements in the hair samples of haemodialysed patients with micro-PIXE, Journal of Analytical Atomic Spectrometry.14:553-557.

[9] Katz, S. A., Chatt, A. (1988). Hair analysis. Application in the biomedical and environmental science,

[10] VCH Publishers, New York 1988.. pp 224-254

[11] Samanta G., Sharma, R., Roychowdhury, T. (2004). Arsenic and other elements in hair, nails, and skin- Scales of arsenic victims in West Bengal, India, The Science of the Total Environment. vol. 326, pp. 33-47

[12] Rahman, L., Corns, W. T., Bryce, D. W., Stockwell, P. B (2000). Determination of mercury, selenium, bismuth, arsenic and antimony in human hair by microwave digestion atomic fluorescence spectrometry, Talanta.52:833-843

[13] Bagliano, G., Benischek, F and Huber, I. (1981). A rapid and simple method for the determination of trace metals in hair samples by atomic absorption spectrometry, Analytica Chimica Acta 123:45-56. 
[14] Bruhn, C. G., Neira, J . Y and Valenzuela, G. D. (1999). Determination of cadmium in hair and

[15] blood by tungsten coil electrothermal atomic absorption spectrometry with chemical modifiers. Talanta. 18:537-549

[16] Lech, T. (1991). Studies on binding of some selected metallic elements in biological material - taking hair as a model, Problems of Forensic Sciences. 24/25:39-42.

[17] Markiewicz, R., Hukaowicz, K., Witkowska, A. (2002). Determination of chromium in women's hair by atomic absorption spectrometry with electrothermal atomization, Chemia Analityczna 2002, 47:159-162.

[18] Ashraf, W., Jaffar, M and Mohammad, D. (1994). Age and sex dependence of selected trace metals in scalp hair of urban population of Pakistan, The Science of the Total 151:227-233.

[19] Sreenivasa, Rao K., Balaji, T and Prasada Rao T. (2002). Determination of iron, cobalt, nickel, manganese, zinc, copper, cadmium and lead in human hair by inductively coupled plasma atomic emission spectrometry, Spectrochimica Acta Part B 2002, vol. 57, pp. 1333-1338

[20] Jiang, C and He, F (2003). Spectrofluorimetric determination of trace amounts of beryllium in mineral water and human's hair, Spectrochimica Acta Part A. 59:1321-1328.

[21] Ciszewski, A., Wasiak, W., Ciszewska, W. (1997). Hair analysis. Part 2. Differential pulse anodic stripping voltammetric determination of thallium in human hair samples of persons in permanent contact with lead in their workplace, Analytica Chimica Acta. 343:225-229

[22] Hosseini, A. A., Amirabadi, A and Afarideh, H. (1996). Determination of toxic and non-toxic hair trace elements in tobacco smokers using PIXE and NAA techniques, Nuclear Instruments and Methods in Physics Research B. 109/110:239-242.

[23] Gammelgaard, B., Peters, K and Menne, T. (1991). Reference values for the nickel concentration in human finger nails. $\mathrm{J}$. Trace. Elem. Electrol. Hlth. Dis. 5: 121-123

[24] Raul, A. A and Jevis, R. E (1992). INNA of scalp hair for environmental monitory of Indonesian and canidian population group. J. Radioanal Nucl. Chem. 161: 210-214

[25] Takagi, Y., Matsuda, S., Imai, S., Masuda, T., Vinson, J. A., Mehia, M. C., Puri, B. K and Kaneiwski, A (1986). Trace element in human hair. An international comparison. Bull. Environ. Contam. Toxicol. 36:793-800
[26] Buchancova, J., Vrlik, M., Knizkova, M., Mesco, D and Holko. L (1993). Levels of selected

[27] element (Fe, $\mathrm{As}, \mathrm{Cd}, \mathrm{Pb}, \mathrm{Zn}, \mathrm{Mn}$ ) in biological samples from ferrochromium workers. Bratisl Lek. Listy. 94: 373-387

[28] Barbosa, F., Tanus-Santos, J., Gerlach, F and Jarsons, P. (2005). Environ. Health Perspect. 113, 1

[29] Sonofonte, O., Violante, N and Caroli, S. (2000). Assess of reference valves for element in human hair of urban schoolboys. J. Trace Elements Med. Bio., 14: 6-13.

[30] International Occupation Safety and Health Information Centre. (1999). Prevention today. 5(3): 1-12

[31] WHO, World Health Organization, (1995). Environmental Health Criteria 165: Inorganic Lead, Geneva: International Programme on Chemical Safety. World Health Organization, Geneva.

[32] Kabata, H and Pendias, A (1993). Trace Elements in Soil and Plants, 2nd Edn., Boca Boca Raton FL, USA, 365, Lewis, 1993

[33] Ward, N. I., Spyrou, N. M and Damyanova, A. A (1988). Study of hair element content from an urban Bulgaria population using NAA assessment of environmental status. J. Radianal Nucl. Chem. 114: 125-135

[34] Turnland, J. R. (1988). Copper nutrition, Bioavailabilty and influence of dietary factors. Journal of American Dietetic Association 1, $303-308$.

[35] Grosell, M.H., C. Hogstrand and C.M. Wood, 1997. Copper uptake and turnover in both copper acclimated and non-acclimated rainbow trout (Oncorhynchus mykiss). Aquat. Toxicol., 38: 257-276.

[36] Gomez, A. J. L., Giráldez, I., Sánchez-rodas, D. (2000). Morales E Comparison of the feasibility of three extraction procedures for trace metal partitioning in sediments from south west Spain. Science Total Environment 246, 271-283.

[37] Kamakura, M. A. (1983). Study of the characteristic of trace elements in the hair of Japanese- Reference values, the trace element patterns for determining normal levels. J. Hyg. 28: 823-838

[38] Divrikli, U., Saracoglu, S., Soylak, M., Elci, L., 2003, De-termination of trace heavy metal contents of green vegetables samples from Kayseri-Turkey by flame atomic absorption spectrometry., Fresenius Environ. Bull., 12, $1123-1125$ 